Pathophysiology of Haemostasis and Thrombosis
Pathophysiol Haemost Thromb 2003;33:134-137

DOI: $10.1159 / 000077821$
Received: July 8, 2003

Accepted after revision: October 24, 2003

\title{
Recurrent Pregnancy Loss and Its Relation to FV Leiden, FII G20210A and Polymorphisms of Plasminogen Activator and Plasminogen Activator Inhibitor
}

\author{
Cornelia E. Wolf a Hannelore Haubelte Hans Ulrich Pauerd Bernd Hinney ${ }^{d}$ \\ Claudette Krome-Cesar $^{c}$ Tobias J. Legler ${ }^{a}$ Peter Hellstern ${ }^{\text {e }}$ Günter Emons ${ }^{d}$ \\ Barbara Zoll ${ }^{b}$ Michael Köhler ${ }^{a}$ \\ Departments of a Transfusion Medicine, ${ }^{\mathrm{b}}$ Genetics, ${ }^{\mathrm{c}}$ Immunology and d Gynecology, University of Göttingen, \\ Göttingen; ' Department of Transfusion Medicine and Hemostaseology, Klinikum Ludwigshafen, \\ Ludwigshafen, Germany
}

\section{Key Words}

Abortion · PAl-1 gene polymorphism · t-PA Alu I gene polymorphism $\cdot$ Factor $V$ Leiden mutation

\begin{abstract}
Thrombophilic disorders and hypofibrinolysis were demonstrated to be risk factors in a majority of women with recurrent pregnancy loss (RPL) and infertility. We investigated the association of FV G1691A mutation, F II G20210A gene polymorphism (PM), 4G/5G PAl-1 and Alu I/D tPA PM in 32 women with infertility and 49 women with at least 2 unexplained early abortions. FV Leiden mutation was significantly more common in women with RPL $(10 \%, p=0.02)$ and infertility $(19 \%, p=0.0005)$ compared with controls (2\%). PAI-1 4G PM and t-PA Alu I $\mathrm{PM}$, alone or in combination, were not associated with RPL or infertility. 9/49 women with RPL showed coagulation disorders with heterozygous FV Leiden mutation (5), FXII (1), protein C (1) or protein S (2) deficiency. However, due to the small number of patients studied, no definite conclusion can be drawn.
\end{abstract}

Copyright $\odot 2003$ S. Karger AG, Basel

\section{Introduction}

Infertility and miscarriages frequently occur in women desiring to have children. The reported early loss rates in clinically detected pregnancies range from 12 to $15 \%$, with an even greater subclinical embryonic loss rate. Most losses occur in early pregnancy, i.e. before 19 weeks of gestation [1]. Owing to the possibility of very early losses prior to the detection of pregnancy, it has even been proposed that miscarriage and infertility should be considered as one group when designing clinical trials [2].

The perception of infertility as a problem is growing. In $1995,10 \%$ of women in the United States at the reproductive age of 15-44 years reported a fecundity impairment [3]. The World Health Organization has published reports that the prevalence of infertility in industrialized countries may be as high as $10-20 \%$. Others indicate that, although the number of women having problems conceiving or carrying a pregnancy to term may drop initially, the numbers will rise to between 4.8 and 5.9 million by the year 2020 [4].

Once infertility has been overcome by such methods as in vitro fertilization (IVF) or intracytoplasmatic sperm

\begin{tabular}{ll}
\hline KARGER & ( ) 2003 S. Karger AG, Basel \\
1424-8832/03/0333-0134\$19.50/0 \\
$\begin{array}{l}\text { Fax +41 61 306 1234 } \\
\begin{array}{l}\text { E-Mail karger@karger.ch } \\
\text { www.karger.com }\end{array}\end{array}$ & $\begin{array}{l}\text { Accessible online at: } \\
\text { www.karger.com/pht }\end{array}$
\end{tabular}

Cornelia Wolf, MD

Department of Transfusion Medicine, University of Göttingen

Robert-Koch-Strasse 40

DE-37075 Göttingen (Germany)

Tel. +49 551 398690, Fax +49551 398691, E-Mail cwolf@med.uni-goettingen.de 
injection (ICSI), the ability to produce live offspring may still remain impaired. At least $2 \%$ of women of reproductive age suffer two or more consecutive spontaneous abortions and approximately $1 \%$ have three and more miscarriages [5].

The causes or clinical factors associated with recurrent miscarriage are chromosome abnormalities, anatomical alterations of the uterus, endocrinologic abnormalities, and autoimmune disorders [5]. Convincing evidence that patients with inherited thrombophilic disorders run a higher risk for recurrent pregnancy loss (RPL) has prompted many investigators to study the frequency of hemostatic abnormalities in patients with RPL [6].

Particularly women with factor V Leiden mutations prove to be at a significantly higher risk for RPL [6]. However, it is currently impossible to ascertain a biochemical or genetic RPL risk factor in most patients. In a large study on more than 500 women with RPL and infertility, $47 \%$ showed a decreased response in the venous occlusion test [7]. The majority was found to have either an increased basal activity of plasminogen activator inhibitor (PAI), increased basal tissue levels of plasminogen activator (t-PA) or both [7]. Recent studies have detected PAI type 1 and t-PA polymorphisms possibly associated with hypofibrinolysis and thrombotic complications [8]. To further explore these findings, we performed a prospective, cross-sectional study to investigate the association of the 4G/5G PAI-1 and the Alu I/D t-PA polymorphisms with infertility and recurrent pregnancy loss.

\section{Materials and Methods}

In this cross-sectional study, we enrolled 32 patients with a history of 1-14 in vitro fertilizations (IVF) or intracytoplasmatic sperm injections (ICSI) and 49 women with at least 2 unexplained early abortions (2-5 abortions, mean 3.0; 31 of these 49 had had at least 3 early abortions). 102 healthy women without abortions or thrombophilic episodes in the family served as controls. All patients suffering from infertility were examined for chromosomal or anatomical abnormalities, genital system infections, endocrinological disturbances of thyroid, LH, FSH, DHEAS, prolactin, testosterone, presence of antiphospholipid antibodies and thrombophilic disorders. One woman with RPL was positive for lupus anticoagulants. 19 of the 49 patients described here with RPL were also part of a study conducted by Pauer et al. [submitted for publication], which focuses on the prevalence of factor $\mathrm{V}$ Leiden mutations, prothrombin G20210A and C677T in the methylene tetrahydrofolate reductase (MTHFR) gene. The median age of IVF patients was 33.1 years (25.9-43.7), of RPL patients 31.9 (24.7-40.3) and of the controls 33.1 (28.0-47.0). The patients gave their informed consent. The study was approved by the local ethics committee (reference No. 5/ 11/99).

Recurrent Pregnancy Loss and FV-, FII-, t-PA and PAI-1-PM
Peripheral blood was collected for coagulation assays in $0.1 \mathrm{M}$ sodium citrate at a ratio of 1:10 (Sarstedt, Nümbrecht, Germany). Blood for coagulation was immediately centrifuged and kept frozen at $-40^{\circ} \mathrm{C}$. No coagulation analyses were performed on 5 samples from IVF patients due to a delay of more than $4 \mathrm{~h}$ between collection and analysis. Blood for genomic analyses was collected in K-EDTA tubes (Sarstedt). The extracted DNA was stored at $4{ }^{\circ} \mathrm{C}$.

\section{Determination of Genotype}

For DNA isolation, we used the QIAmp Blood Kit (Qiagen, Hilden, Germany) or a salting out technique [9]. The $4 \mathrm{G} / 5 \mathrm{G}$ polymorphism of the PAI-1 gene promoter was investigated with an allelespecific PCR method [10]. The I/D polymorphism of the t-PA gene resulting from the presence or absence of an Alu repeat between exon 8 and 9 was analyzed according to a slightly modified protocol of van der Bom et al. [11]. Our modification used PCR beads (Ready To Go Beads, Pharmacia Biotech, Freiburg, Germany), 0.65 $\mu 1$ DMSO $(2.5 \%)$ and $12.5 \mathrm{pmol} / \mathrm{PCR}$ of each primer in a total volume of $25 \mu 1$. After denaturation for $3 \mathrm{~min}$ at $94^{\circ} \mathrm{C}, 301$-min cycles were performed at $94^{\circ} \mathrm{C}$, for $1 \mathrm{~min}$ at $66^{\circ} \mathrm{C}$ and $2 \mathrm{~min}$ at $72^{\circ} \mathrm{C}$ followed by a final 5-min elongation step at $72^{\circ} \mathrm{C}$. PCR products were visualized in $1 \%$ agarose gel containing $10 \mathrm{mg} / \mathrm{ml}$ ethidium bromide. G1691A polymorphism of the factor V gene was investigated by PCR-RFLP using restriction enzyme MnlI [12]. The HindIII restriction enzyme was used for PCR-RFLP analysis of G20210A polymorphism of the prothrombin gene [13].

\section{Assays}

All clotting assays were performed on a coagulation analyzer (STA; Roche Diagnostics, Mannheim, Germany). AT and protein S activity were measured as described elsewhere [14]. Protein C activity was determined by a chromogenic substrate assay (Chromogenix, Mölndal, Sweden). Factor XII was measured by a one-stage clotting assay using human deficient plasma from Immuno (Vienna, Austria). The normal ranges were: AT 80-120 U/dl, PC 70-149 U/dl, PS 50-120 U/dl, FXII 50-150 U/dl.

\section{Statistical Methods}

Results were compared by Pearson's $\chi^{2}$ test. $\mathrm{p}<0.05$ was assigned statistical significance. Odds ratios and 95\% confidence intervals were calculated. Statistical analyses were performed with Statistica (Statsoft, Hamburg, Germany).

\section{Results}

Coagulation abnormalities were only found in 4 of 49 patients suffering from RPL. One patient had a factor XII deficiency $(48 \mathrm{U} / \mathrm{dl}), 1$ a protein $\mathrm{C}$ deficiency $(65 \mathrm{U} / \mathrm{dl})$ and 2 a protein $\mathrm{S}$ deficiency $(21$ and $39 \mathrm{U} / \mathrm{dl})$. A heterozygous factor $\mathrm{V}$ Leiden mutation was detected in 5 of these 49 patients $(10 \%$, control group $n=2,2 \%, p=0.02$, odds ratio 5.68, 95\% CI 1.06-30.40). A heterozygous factor $\mathrm{V}$ Leiden mutation $(\mathrm{p}=0.0005$, odds ratio $11.54,95 \% \mathrm{CI}$ 2.20-60.60) was observed in 6 out of $32(19 \%)$ infertile women in our study. The factor II 20210A allele was not detected in IVF and RPL patients (controls $n=2 ; 2 \%$ ).

Pathophysiol Haemost Thromb 2003;33:134-137 
Table 1. PAI-1 4G/5G and t-PA Alu I/D gene polymorphisms in women with recurrent pregnancy loss

\begin{tabular}{lccc}
\hline & $\begin{array}{l}\text { Recurrent } \\
\text { miscarriage } \\
(\mathrm{n}=49)\end{array}$ & $\begin{array}{l}\text { Controls } \\
(\mathrm{n}=102)\end{array}$ & p value \\
\hline PAI-1 5G/5G & $7(14 \%)$ & $20(20 \%)$ & 0.49 \\
PAI-1 4G/5G & $25(51 \%)$ & $50(49 \%)$ & \\
PAI-1 4G/4G & $17(35 \%)$ & $32(31 \%)$ & \\
t-PA D/D & $10(20 \%)$ & $19(19 \%)$ & 0.71 \\
t-PA I/D & $27(55 \%)$ & $49(48 \%)$ & \\
t-PA I/I & $12(25 \%)$ & $34(33 \%)$ & \\
\hline
\end{tabular}

Recurrent miscarriage was not associated with the PAI-1 4G allele (odds ratio $1.46,95 \%$ CI $0.57-3.73$ ) or with the t-PA Alu I allele (odds ratio $0.89,95 \%$ CI 0.38 2.09) (table 1). Nor were these two alleles found to be associated with infertility. Moreover, the combination of PAI-1 4G gene polymorphism and t-PA Alu I gene polymorphism was not higher in patients suffering from RPL $(p=0.25)$ or undergoing IVF $(p=0.57)$. The genotype frequencies were consistent with the distribution predicted by the Hardy-Weinberg equation.

\section{Discussion}

Relationships have been demonstrated to exist between familial disorders of the hemostatic system and recurrent pregnancy loss. Several studies have demonstrated that women with inherited thrombophilias carry a higher risk for recurrent early miscarriages, second-trimester abortion and other complications of pregnancy [6]. Conversely, inherited thrombophilia is found in only a small, but in some studies significant, proportion of cases when screening for RPL. Factor V Leiden mutation might be a significant risk factor with a reported incidence of $8-32 \%$ in patients and $4-10 \%$ in controls [6]. Although factor V Leiden had an impact on risk in our study, this finding could not be confirmed in a larger sample [Pauer et al. 2003, submitted for publication]. Thus, it is still unclear whether factor V Leiden mutation and factor II G 20210 A polymorphism are significant risk factors [15, 16]. The largest study so far on more than 1,000 women did not find any correlation between mutations in these two genes and RPL [17]. This finding was confirmed by Pauer et al. [submitted for publication]. Their study failed to demonstrate a relationship between RPL and FV Lei- den mutation, prothrombin G20210A and C677T in the MTHFR gene. Only 8 of our 49 patients had either factor $\mathrm{V}$ Leiden, protein $\mathrm{C}$ or protein S deficiency.

A mild FXII deficiency was detected in 1 single patient. These data are not consistent with our own results and other earlier reports [7, 18, 19]. The reason for these inconsistent results remains obscure. There is convincing evidence that placental insufficiency plays a major role in late fetal loss. Factor V Leiden and prothrombin $G$ 20210A have been associated with late fetal loss and abnormal placentas on pathological examination [20]. Thus, a distinction must be made between early recurrent miscarriage and late fetal loss and stillbirth. Indeed, the total number of patients studied has only limited influence, since the largest studies failed to show significant results. Even though ethnic differences may play a role, perhaps more importantly, consideration should be given to the possibility of an acquisition bias for RPL when hemostasis centers are involved in the selection of patients [17]. Hence, thrombophilic disorders can currently explain infertility and early recurrent miscarriages in only a small number of these patients. The majority of cases remains unexplained.

In a study on 500 patients with recurrent abortion, Gris et al. [7] reported higher levels of t-PA and PAI in addition to an insufficient response to the venous occlusion test. These abnormalities of the fibrinolytic system were observed in $42-47 \%$ of patients. However, these parameters are difficult to standardize and are often not reliable. Even large studies on patients with venous thrombosis yielded contradicting results. Thus, such tests are of limited value [21].

Assessment of fibrinolysis gene polymorphisms may overcome some of the methodological problems associated with conventional fibrinolysis assays. Several nucleotide sequence polymorphisms have been identified within the t-PA gene locus. The Alu insertion/deletion (I/D) within the intron between exons 8 and 9 has been investigated in several studies due to reports that this polymorphism influences the release rates of total t-PA. Disappointingly, the results of these studies were also inconsistent, and still keep us in the dark about the significance of the Alu I/D polymorphism [8, 22]. Recently, though, three novel t-PA gene polymorphisms have been described which are in strong linkage disequilibrium with Alu polymorphism and influence the t-PA release [23]. It remains to be established whether these newly discovered polymorphisms are strong risk factors for thrombotic disease and thereby recurrent abortion. 
The PAI-1 gene also has several polymorphic loci, whereby the $4 \mathrm{G} / 5 \mathrm{G}$ insertion/deletion -675 bp upstream from the transcriptional start site may play a role in the regulation of fibrinolysis. Several studies have reported up to $25 \%$ higher levels of PAI- 1 in homozygous $4 \mathrm{G}$ individuals than in $5 \mathrm{G} / 5 \mathrm{G}$ subjects. As was the case with t-PA Alu I/D polymorphism; however, the results of studies investigating a possible relationship between the $4 \mathrm{G} / 5 \mathrm{G}$ polymorphism and the risk of myocardial infarction were contradictory. If such polymorphisms do exert a significant effect on myocardial infarction, it appears to be weak [8].
Glueck et al. [24] detected a significantly increased incidence of the hypofibrinolytic $4 \mathrm{G} / 4 \mathrm{G}$ polymorphism (odds ratio 2.0) in 94 women with obstetric complications including severe preeclampsia, abruptio placentae, fetal growth restriction and stillbirth. By contrast, we were unable to observe that PAI-1 4G gene polymorphism and t-PA Alu I gene polymorphism, either alone or in combination, had any effect on miscarriage risk in RPL patients in this small study. Larger studies are obviously required to assess the possible role of these fibrinolytic polymorphisms in RPL. Furthermore, other polymorphisms of tPA and PAI-1 may be involved that influence fibrinolysis and have an impact on the risk of obstetric complications and infertility.

\section{References}

1 Stirrat GM: Recurrent miscarriage. I. Definition and epidemiology (review). Lancet 1990; 336:673-675.

2 Karrison TG, Ober C: Recurrent miscarriage (REMIS) study: How should data from women who do not become pregnant be handled? Control Clin Trials 1998;19:430-439.

3 Chandra A, Stephen EH: Impaired fecundity in the United States: 1982-1995. Fam Plan Perspect 1998;30:34-42.

4 Stephen EH: Projections of impaired fecundity among women in the United States: 1995 to 2020. Feril Steril 1996;66:202-204.

5 Stirrat GM: Recurrent miscarriage. II. Clinical associations, causes, and management (review). Lancet 1990;336:728-733.

6 Brenner B: Inherited thrombophilia and pregnancy loss (review). Thromb Haemost 1999; 82:634-640.

7 Gris JC, Ripart-Neveu S, Maugard C, Tailland ML, Brun S, Courtieu C, Biron C, Hoffet M, Hédon $\mathrm{B}$, Màres $\mathrm{P}$ : Prospective evaluation of the prevalence of haemostasis abnormalities in primary early recurrent miscarriages. Thromb Haemost 1997;77:1096-1103.

8 Lane DA, Grant PJ: Role of hemostatic gene polymorphisms in venous and arterial thrombotic disease (review article). Blood 2000;95: 1517-1532.

9 Miller SA, Dykes DD, Polesky HF: A simple salting out procedure for extracting DNA from human nucleated cells. Nucleic Acids Res 1988; $16: 1215$.
10 Falk G, Svensson H, Almqvist A, Wiman B: Allele specific PCR for detection of a sequence polymorphism in the promotor region of the plasminogen activator inhibitor-1 (PAI-1) gene. Fibrinolysis 1995;9:170-174.

11 van der Bom JG, de Knijff P, Haverkate F, Bots ML, Meijer P, de Jong PT, Hofman A, Kluft C, Grobbee DE: Tissue plasminogen activator and risk of myocardial infarction. Circulation 1997;95:2623-2627.

12 Ridker PM, Hennekens CH, Lindpaintner K, Stampfer MJ, Eisenberg PR, Miletich JP: Mutation in the gene coding for coagulation factor $\mathrm{V}$ and the risk of myocardial infarction, stroke, and venous thrombosis in apparently healthy men. N Engl J M 1995;332:912-917.

13 Poort SR, Rosendaal FR, Reitsma PH, Bertina $\mathrm{RM}$ : A common genetic variation in the 3'untranslated region of the prothrombin gene is associated with elevated plasma prothrombin levels and an increase in venous thrombosis. Blood 1996;88:3698-3703.

14 Haubelt $\mathrm{H}$, Blome M, Kiessling AH, Isgro F, Bach J, Saggau W, Hellstern P: Effects of solvent/detergent-treated plasma and fresh-frozen plasma on haemostasis and fibrinolysis in complex coagulopathy following open-heart surgery. Vox Sang 2002;82:9-14

15 Pickering W, Holmes Z, Regan L: Normal prevalence of the G20210A prothrombin gene mutation in women with recurrent miscarriage (abstract). Br J Haematol 1998;102:250.

16 Yamada H, Kato EH, Kobashi G, Ebina Y, Shimada S, Morikawa M, Yamada T, Sakuragi N, Fujimoto S: Recurrent pregnancy loss: etiology of thrombophilia. Semin Thromb Hemost 2001;27:121-129.
17 Rai R, Shlebak A, Cohen H, Backos M, Holmes Z, Marriott K, Regan L: Factor V Leiden and acquired activated protein $\mathrm{C}$ resistance among 1,000 women with recurrent miscarriage. Hum Reprod 2001;16:961-965.

18 Braulke I, Hinney B, Pruggmyer M, Köstering H, Melloh P, Günther E: Factor (Hagemann) XII deficiency in women with habitual abortion: New subpopulation of recurrent aborters? Fertil Steril 1993;59:98-101.

19 Schloesser M, Zeerleder S, Lutze G, Halbmayer WM, Hofferbert S, Hinney B, Koestering $\mathrm{H}$, Lämmle $\mathrm{B}$, Pindur $\mathrm{G}$, Thies $\mathrm{K}$, Köhler M, Engel W: Mutations in the human factor XII gene. Blood 1997;90:3967-3977.

20 Martinelli I, Taioli E, Cetin I, Marinoni A, Gerosa S, Villa MV, Bozzo M, Mannucci PM: Mutations in coagulation factors in women with unexplained late fetal loss. N Engl J Med 2000;343:1015-1018.

21 Bauer KA: Conventional fibrinolytic assays for the evaluation of patients with venous thrombosis: Don't bother. Thromb Haemost 2001; 85:377-378.

22 Franco RF, Reitsma PH: Gene polymorphisms of the haemostatic system and the risk of arterial thrombotic disease. Br J Haematol 2001; 115:491-500.

23 Ladenvall P, Wall U, Jern S, Jern C: Identification of eight novel single-nucleotide polymorphisms at human tissue-type plasminogen activator (t-PA) locus: Association with vascular tPA release in vivo. Thromb Haemost 2000;84: 150-155.

24 Glueck CJ, Kupferminc MJ, Fontaine RN, Wang P, Weksler BB, Eldor A: Genetic hypofibrinolysis in complicated pregnancies. Obstet Gynecol 2001;97:44-48. 